\title{
Stratigraphic Control of Petrography and Chemical Composition of the Lower Gondwana Coals, Ib-Valley Coalfield, Odisha, India
}

\author{
Alokranjan Senapaty, P. Behera \\ Post Graduate Department of Geology, Utkal University, Bhubaneswar, India \\ Email: alok.senapaty@gmail.com, purnananda.behera@gmail.com
}

Received 3 May 2015; accepted 27 June 2015; published 30 June 2015

Copyright (C) 2015 by authors and Scientific Research Publishing Inc.

This work is licensed under the Creative Commons Attribution International License (CC BY). http://creativecommons.org/licenses/by/4.0/

\section{(c) (i) Open Access}

\section{Abstract}

The Ib-valley coalfield of Odisha, India contains five coal seams viz. Ib-seam at the bottom overlain successively by Rampur seam, Lajkura seam, Parkhani seam and Belpahar seam. Twenty one representative samples were collected from three major seams (Ib, Rampur and Lajkura) and their petrography and chemical studies were carried out. Samples were not collected from the Parkhani and Belpahar seams as these are very small seams exposed locally having no regional correlation. The macroscopic study shows the dominance of durain which imparts a dull appearance to these coals. The maceral analysis reveals that vitrinite percentage varies from $4.5 \%$ to $80.2 \%$, the exinite from $3.30 \%$ to $22.2 \%$ and the inertinite from $12.5 \%$ to $92.2 \%$ in different samples of the Ib valley coalfield. The very high proportion of inertinite suggests a shallower water deposition of plant materials followed by prolonged period of exposure and repeated cycle of weathering. The proximate analysis results show that the top Lajkura seam is comparatively lower in rank than the underlying $\mathrm{Ib}$ and the Rampur seam. The ultimate analysis exhibites that the percentage of variation in $\mathrm{C}$ is found from 77.88 to $85.79, \mathrm{H}$ from 4,4 to 5.91 and $\mathrm{O}$ from 7.26 to $15.3 \mathrm{H} / \mathrm{C}$ and $0 / \mathrm{C}$ ratio including C.V. in this coalfield showing distinct variations from the bottom to top seam. The analyses results indicate that the petrographic and chemical characters of the ib valley coals are stratigraphically controlled.

\section{Keywords}

Petrography, Chemical Analysis, Lower Gondwana, Ib-Valley Coalfield, Odisha, India 


\section{Introduction}

The Ib-valley coalfield derives its name after the river Ib, a tributary of the river Mahanadi and represents a part of the NE-SW trending master basin belt of the Son-Mahanadi valley. The river flows in a general southerly direction through the coalfield and discharges into Hirakud reservoir, which has submerged the southern fringe of the coalfield. The Ib-valley comprises Hingir basin in the north and the Rampur basin in the south. Though the Gondwana sediments spread further north-west into the adjoining parts of Chhatisgarh state and comprise the Mand-Raigarh and the Korba coalfields, the limits of the Ib-valley coalfield are defined by political boundary and covers parts of Sambalpur, Jharsuguda and Sundargarh districts of Odisha. The coalfield extends over an area of $1460 \mathrm{sq} \mathrm{km}$ and is bounded by latitudes $21^{\circ} 31^{\prime} \mathrm{N}$ and $22^{\circ} 14^{\prime} \mathrm{N}$ and longitudes $83^{\circ} 32^{\prime} \mathrm{E}$ and $84^{\circ} 10^{\prime} \mathrm{E}$.

A few researchers have yet carried out their research activities on this coalfield of Mahanadi valley. Pareek (1958) [1] was the first person to study the microstructure and petrological composition of the Rampur seam and found that these coals comprised fibrous durain and fine grained durain, vitrinite being abundant in the former and occurring as long parallel strips, while in the latter, it was of micro-fragmental nature an sporadic. Exinite and fusinite occur interbedded with vitrinite sheets. Semi-fusinite, sclerotinite, micrinite, resinite and cutinite occur next in abundance. Subsequently, Navale (1967) [2] published the micro-constitutional analysis of the coals of Rampur coalfield and Navale and Tiwari (1968) [3] ventured the palynological correlation of coal seams, their nature and formation in the Rampur coalfield. The spontaneous combustion of the Ib-valley coalfiled was studied by Behera and Chandra (1995) [4] and correlations were drawn between macerals and crossing point temperature (CPT).

Goswami et al. (2006) [5] carried out the study of floristic assemblage during the deposition of Barakar and Kamthi Fomation and had suggested a palaeoclimatic shift from temperate warm moist to warm dry condition during upper Barakar Fomation and a warm and humid condition during the Kamthi Fomation. Based on the study of petrochemistry of the coals of the Basundhara block of the Ib-valley coalfield, Singh et al. (2010) [6] suggested that these coals originated from the plant communities of highly fluctuating oxic and anoxic moor to oxic (dry) moor with sudden high flooding condition. Mohanty et al. (2011) [7] studied the petrographic signature of marine inundation from the Barakar coals of the Ib-valley and opined that this inundation was caused by a rise in the mean sea level of the Tethys sea following a phase of deglaciation till the isostatic equilibrium was achieved. A study of trace elements in the coal indicates that the seam belonging to the Karharbari Formation is more enriched with trace elements than the seam belonging to the Barakar Formation (Senpaty and Behera, 2012) [8]. Singh et al. (2013) [9] studied the petrology of the coals of the Rampur seam-IV and the Lajkura seam and found the dominance of inertinite group for macerals and mineral matter content.

In this research paper, an attempt has been made to see the variation of chemical parameters and petrographical studies in relation to stratigraphy.

\section{Geology}

The first ever geological map of the area was prepared by V. Ball in 1875. Drilling operation was initiated by W. King in 1884-86.The area was subsequently remapped by G.F. Reader (1901), G.C. Chatterjee (1943), E.R. Gee (1947), DRS Mehta and M.A. Anandalwar (1954-55). Large scale mapping on 1: 31,680 scale, with the aid of aerial photographs on 1: 42,240 scale, was carried out by B.C. Pandey and S.N. Chakraborty during 1961-63. However, the regional exploration by GSI has been started only from 1964-65. The Directorate of Geology, Government of Orissa is engaged in detailed exploration in this coalfield on behalf of CMPDI since 1974-75. The Geological map of the Ib-valley coalfield area is shown in Figure 1.

The stratigraphic succession (Table 1) starts with precambrian rocks at the base. Gondwana Formations consisting mainly the Talchir, Karharabari, Barakar, lower Kamthi (Raniganj) and upper Kamthi Formation overlie the Precambrian rocks and at the top recent deposits are found. The upper Kamthi Sediments are of Triassic and other are of Permian time.

The Karharbari and Barakar Formations are the major coal bearing formations the Ib-valley coalfields, though rare occurrence of coal seams in Raniganj Formation has been reported by GSI. Based on the status of present knowledge of surface and sub-surface data, there appears to be a total of 5 coal seams in the Ib-valley coalfield (Manjrekar et al., 2006) [10]. The Ib-seam, being the bottommost seam is successively overlain by the Rampur seam, the Lajkura seam, the Parkhani seam and the Belpahar seam (Table 2). Out of the above, only the Ib seam belongs to the Karharbari Formation where as the other seams belong to the Barakar Formation. The Belpahar 


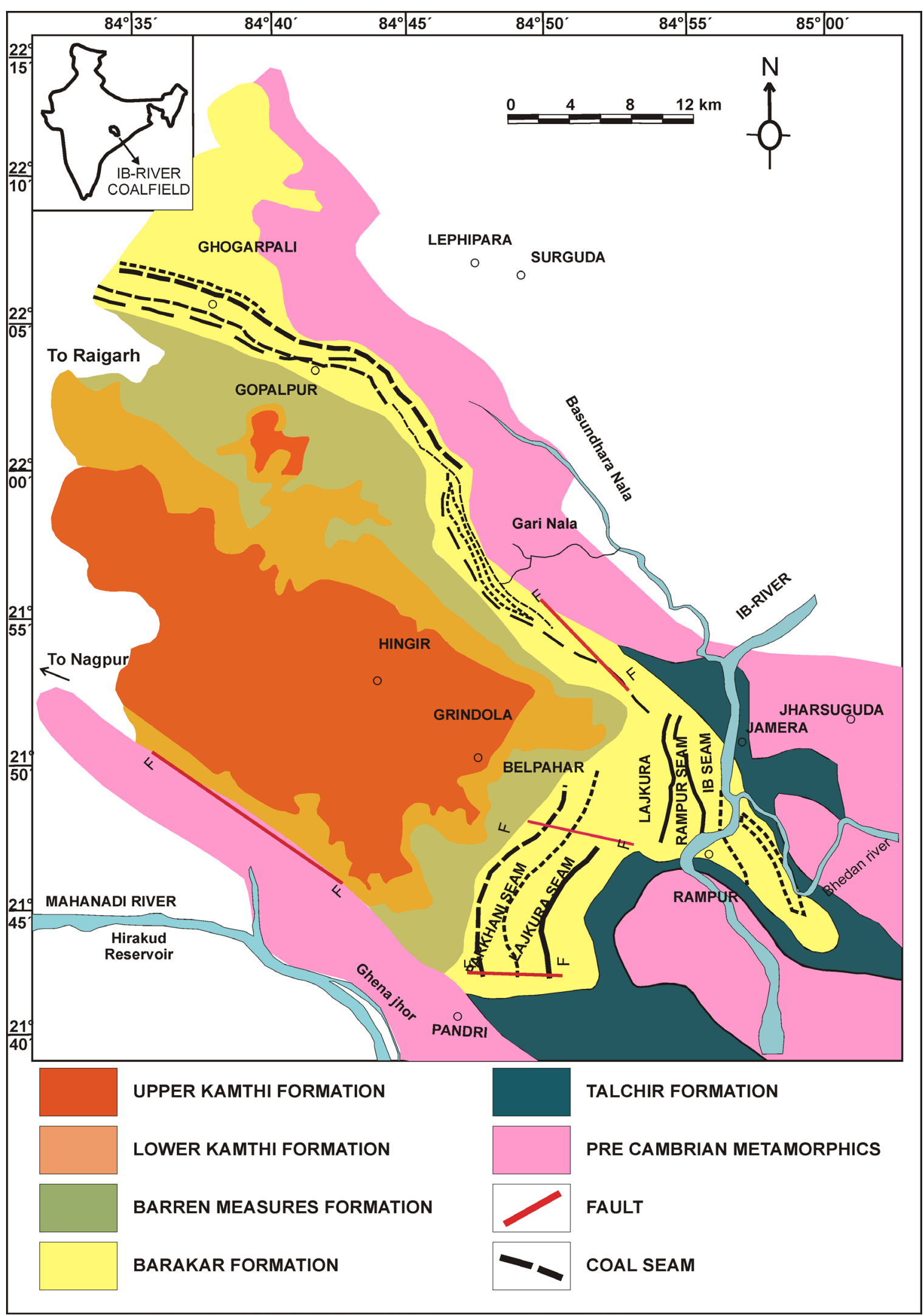

Figure 1. Geological map of the Ib valley coalfield area (after Goswami, 2006). 
Table 1. Geological succession of the Ib-valley coalfield (after Manjrekar et al., 2006).

\begin{tabular}{|c|c|c|}
\hline Age & Formation & Lithology \\
\hline Recent & & $\begin{array}{l}\text { Alluvium; sand, silt and clay of older alluvium, younger flood plain deposits, } \\
\text { channel fills etc. }\end{array}$ \\
\hline Sub-Recent & & Laterites/recent gravel and conglomerate beds. \\
\hline Up. Permian to & Kamthi (Upper) = Raniganj & Conglomerates, pebbly and ferruginous sandstones and red shales. \\
\hline Lower Triassic & Kamthi $($ Lower $)=$ Barren measures & Gray shales, carbonaceous shales, sandstone, clay and iron stone nodules. \\
\hline \multirow{3}{*}{ Lower Permian } & Barakar & Gray sandstone, carbonaceous Shale, silt stone with thick coal seams and fire clay. \\
\hline & Karharbari & Black carbonaceous sandstone, pebble bed, coal seams. \\
\hline & Talchir & Dimictite, greenish sand stone, olive and chocolate shales, rhythmites. \\
\hline Precambrian & & Granite gneisses, amphibolites, migmatites etc. \\
\hline
\end{tabular}

Table 2. Succession of coal seams in the Ib-valley coalfield (after Manjrekar et al., 2006).

\begin{tabular}{cc}
\hline Seam/Coal Horizon & Thickness Range (m) \\
\hline Belpahar Coal Horizon & $24-30$ \\
Parting & $105-195$ \\
Parkhani Coal Horizon & $0.5-1.0$ \\
Parting & $92-120$ \\
Lakura Seam & $15-89$ \\
Parting & $16-112$ \\
Rampur Coal Horizon & $27-80$ \\
Parting & $3-55$ \\
Ib Seam & $2-10$ \\
\hline
\end{tabular}

and Parkhani seams possess a poor reserve of coal and are intersected with a number of dirt bands for which emphasis has not been given on the study of these seams.

\section{Petrography}

With the advancement of coal technology, petrography plays an important role for determination of coal quality and its application in various sectors like carbonization, hydrogenation, coal gas production and uses in industries. Therefore, study of petrography was carried out for the Ib valley coals.

\subsection{Method of Study}

Representative samples were collected from the three major coal seams of the Ib-valley coallfield (i.e. the Ib seam, the Rampur Seam and the Lajkura seam). The coal samples were crushed to $-1 \mathrm{~mm}$ size and coal pellets were prepared with cannabau wax. These samples were studied under reflected light with Leitz MPV2 microscope with oil immersion lense and fluorescent attachment following standard procedures (ICCP 1971, 1998, 2001) [11]-[13]. Macerals were identified following ICCP classification of macerals (ICCP 1963, 1971, 1975, 1998, 2001) [11] [12] [14] [15].

\subsection{Macroscopic Description}

Macroscopic observation shows that the Ib River coals are banded and show grayish black to dull black in ap- 
pearance. Durain is the most common macroscopic ingredient followed by clarain. The dominance of durain imparts a dull appearance to these coals. Based on the macroscopic study, the Lajkura seams are constituted of “dull coal”, "banded dull coal”, and "banded coal” (Singh et al., 2013; Diessel, 1965) [9] [16].

\subsection{Microscopic Study/Maceral Analysis}

The results of maceral studies have been shown in Table 3.

Vitrinite group: Vitrinite is the most common constituent of the Ib valley coal samples. The percentage of vitrinite rarely exceeds $77 \%$ (Table 3 ). The vitrinites are massive and cellular types and in general the colour is dark gray to light gray exhibiting moderate to low reflectivity. These are considered as tellicollinite. It is frequently intermixed with exinite, and fragmental bits of fusinite. A few high reflective grains resemble pseudo-vitrinite. In some samples discrete grains of pyrite and siderite are found to be embedded in vitrinite. Vitrinite, telicollinolite and fusinite are the dominant microlithotypes. In some samples vitrinites are seen to preserve resinous bodies.

Excluding mineral matter the vitrinite varies from 4.5\% to 80.2\% (Table 3). Seamwise, the youngest Lajkura seam shows the highest percentage of vitrinite where as the Rampur and Ib seams show comparatively less of vitrinite. In reflected light, duroclarite microlithotype is seen containing macrinite, vitrinite and sporinite with specks of pyrite (Figure 2(a)). Under fluorescence, sporinite becomes fluorescing while vitrinite, macrinite and mineral grains are unfluorescing (Figure 2(b)). In Figure 3(a), vitrinite is found occurring alternately with exinite. Few fragments of fusinite are admixed with vitrinite. This figure when observed under fluorescent light, vitrinite becomes nonfluorescing while exinite is fluorescing (Figure 3(b)).

Exinite: The exinite group of macerals observed in the Ib valley coals are mianly megasporinite, sporinite, cutinite and resinite. Megasporinite and sporinite are the major exinite macerals. In some samples cell sacks of megaspores are filled with secondary resinous material. In most of the samples exinites are admixed with fragmental bits of vitrinite and vice versa. Vitrinites admixed with exinities contain small oval bodies of resinite. In some samples of the Ramur seam, microsporinite and resinite are intimately mixed with fragments of vitrinite, inertinite and are aggregating to duroclarite or clarite microlithotype.

Table 3. Maceral analysis of Ib-valley coals.

\begin{tabular}{|c|c|c|c|c|c|c|}
\hline \multirow{2}{*}{ Sample No. } & \multirow{2}{*}{ Name of the Coal Seam } & \multirow{2}{*}{ Vitrinite } & \multirow{2}{*}{ Exinite } & \multirow{2}{*}{ Inertinite } & \multicolumn{2}{|c|}{ Mineral Matter } \\
\hline & & & & & Pyrite & Other \\
\hline $\mathrm{L} / 5$ & Lajkura & $50(54.4)$ & $06(6.5)$ & $36(39.1)$ & 2 & 6 \\
\hline $\mathrm{L} / 3$ & Lajkura & $77(80.2)$ & $07(7.3)$ & $12(12.5)$ & 1 & 3 \\
\hline $\mathrm{L} / 1$ & Lajkura & $51(52.6)$ & $09(9.3)$ & $37(38.2)$ & 1 & 2 \\
\hline $\mathrm{RS}_{5} / \mathrm{T}$ & Rampur & 25 (27.8) & $20(22.2)$ & $45(50.0)$ & 4 & 6 \\
\hline $\mathrm{RS}_{5} / \mathrm{B}$ & Rampur & $26(29.2)$ & $16(18.0)$ & $47(52.8)$ & 4 & 7 \\
\hline $\mathrm{RS}_{4} / \mathrm{M}$ & Rampur & $22(24.4)$ & $13(14.4)$ & $55(61.2)$ & 4 & 6 \\
\hline $\mathrm{RS}_{3} / \mathrm{T}$ & Rampur & $24(25.0)$ & 19 (19.8) & $53(55.2)$ & 3 & 1 \\
\hline $\mathrm{RS}_{3} / \mathrm{B}$ & Rampur & $04(4.5)$ & $03(3.4)$ & 82 (92.2) & 3 & 8 \\
\hline $\mathrm{RS}_{2} / \mathrm{B}$ & Rampur & 15 (15.9) & 18 (18.2) & 61 (64.9) & 2 & 4 \\
\hline $\mathrm{RS}_{1} / \mathrm{M}$ & Rampur & 47 (42.5) & 11 (11.2) & 41 (41.4) & - & 01 \\
\hline $\mathrm{RS}_{1} / \mathrm{B}$ & Rampur & 33 (33.7) & 12 (12.2) & $53(54.1)$ & 01 & 01 \\
\hline $\mathrm{Ib} / \mathrm{T}$ & $\mathrm{Ib}$ & 65 (66.3) & 12 (12.2) & 21 (21.5) & 01 & 01 \\
\hline $\mathrm{Ib} / \mathrm{M}_{1}$ & $\mathrm{Ib}$ & 34 (35.1) & 20 (20.6) & 43 (44.3) & - & 03 \\
\hline $\mathrm{Ib} / \mathrm{B}$ & $\mathrm{Ib}$ & $51(52.5)$ & 17 (17.6) & 29 (29.9) & 01 & 02 \\
\hline
\end{tabular}




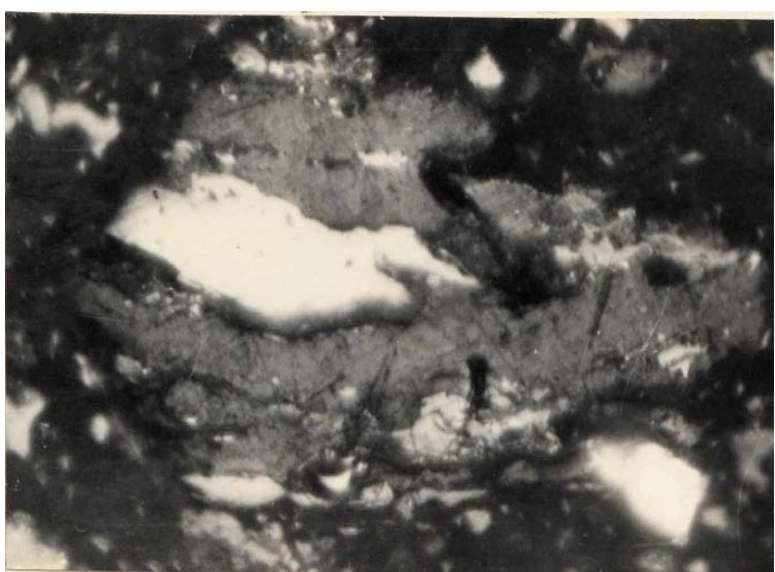

(a)

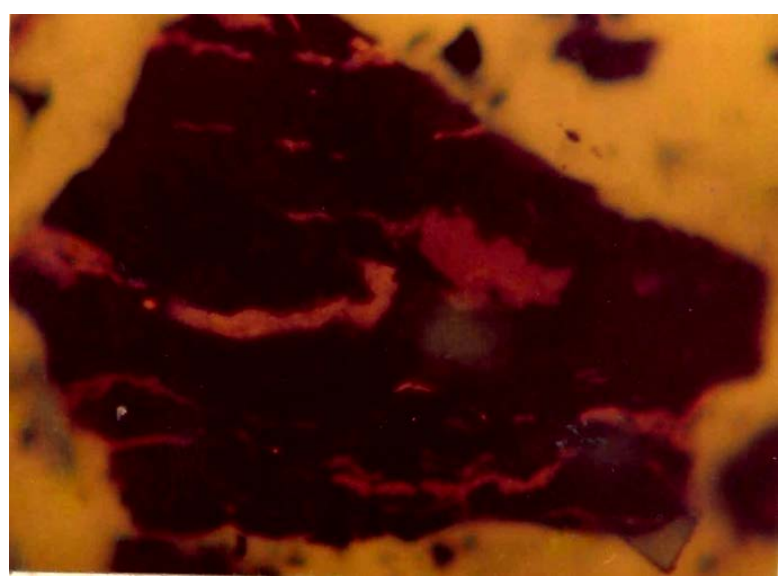

(b)

Figure 2. (a). Duroclarite microlithotype containing macrinite, vitrinite and sporinite with specks of pyrite under reflected light. (b) Duroclarite microlithotype containing macrinite, vitrinite and sporinite with specks of pyrite under fluorescence light.

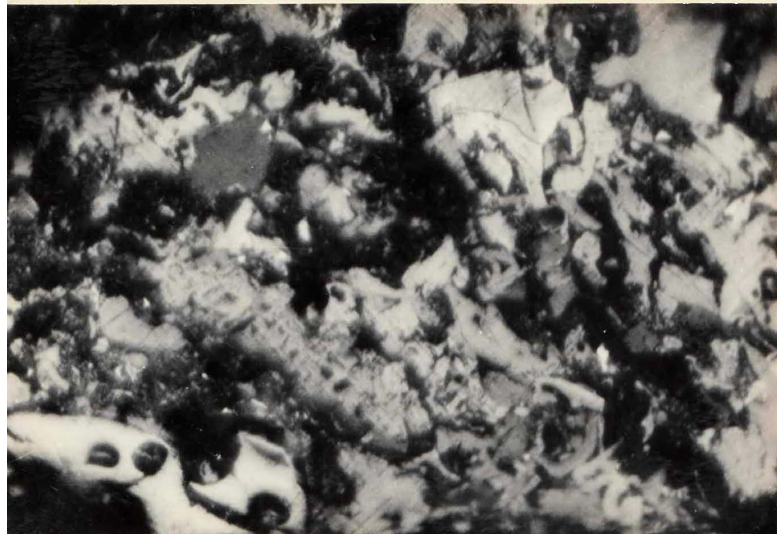

(a)

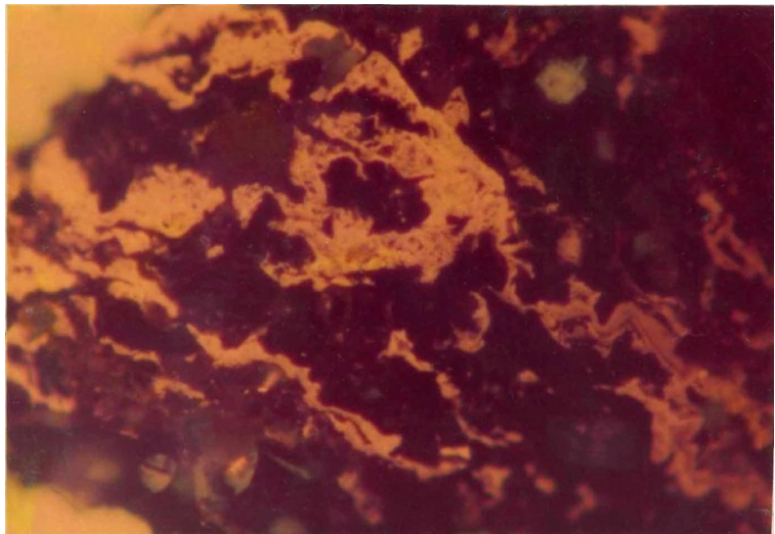

(b)

Figure 3. (a). Vitrinite occurring alternately with exinite under reflected light; (b). Vitrinite occurring alternately with exinite under fluorescent light.

The percentage of exinite in the Ib valley coals vary from 3.3 to 22.2. Normally Indian coals show low exinite content but interestingly the Ib valley coals are high in exinite content suggesting reducing environment. The percentage of exinite is comparatively low in the youngest Lajkura seam where as the percentage is higher in Rampur and the Ib seam. High percentage of exinite was reported by Chandra and Taylor (1975) [17] in Talchir coals. Niyogi (1989) [18] also supported the views of Chandra and Taylor. The authors also find high percentage of exinites in the Ib valley coals. In reflected light, durite is seen comprising fusinite and exinite (Figure 4(a)). When these are observed under fluorescent light, exinite becomes fluorescing while fusinite is non-fluorescing (Figure 4(b)).

Inertinite group: Inertinites are the group of macerals which show highest reflectivity and are very bright in incident light. The micro components of the inertinite group include semi fusinite, fusinite, macrinite, micrinite, scelerotinite, and intertodeterinite. Fusinite is by far the most the dominant maceral in the Ib valley coals. Semi fusinite, macrinite, micrinite and inertodectrinite are other macerals found in decreasing order of abundance. Sclerotinite occurs as a rare component. Micrinite occurs as granular form and is opaque in transmitted light. Fusinite cell lumens are filled with inorganic minerals like pyrite, quartz and siderite. In many samples, fusinites are highly crossed. In some cases fusinite shows well preserved woody structure. Fusinite and semifusinite occur as lensoid bodies and are crossed at many places. Fusinite, vitrinattitte-I and clarodurite are the dominant microlithytypes. 
The percentage of inertinite in the Ib valley coals varies from $12.5 \%$ to $92.2 \%$ on mineral matter free basis (Table 2) and no definite trend in variation of inertinite is seen from bottom seam to the top seam. The very high proportion of inertinite obviously suggests a shallower water deposition of plant materials followed by prolonged period of exposure and repeated cycle of weathering.

In reflected light, an association of fusinite and sporinite is shown (Figure 5(a)). This figure when observed under fluorosecence, sporinite fluoresces and shows yellowish brown colour whereas fusinite remains nonfluorescing (Figure 5(b)).

Mineral matter: The Ib valley coals are found to contain higher portion of mineral matter. The percentage of mineral matter in different samples varies from $1 \%-16 \%$ (Table 2). The mineral matters mainly include clay minerals, siderite, pyrite, limonite, and quartz. Pyrite and siderite are found as inclusions in vitrinites and in some samples they fill up the cell lumens of fusinite along with silicate minerals. In some cases siderite replaces semifusinite bodies. Pyrite and siderite are also found ubiquitously distributed as discrete grains. In the samples of Ib valley coalfields, the pyrite content varies from $1 \%$ to $7 \%$. The authors also find a number of colloidal forms of minerals which are suspected to be melnikovite (variety of pyrite group).

\section{Chemical Analysis}

The chemical analysis of the coals of the Ib-valley coalfield was carried out with a view to know the chemical behavior of these coals in respect of stratigraphy. For this purpose, both proximate and ultimate analyses were

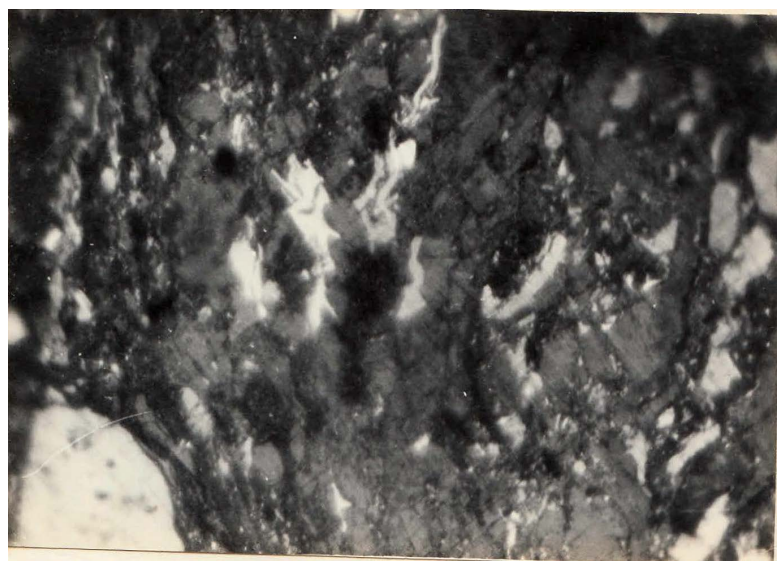

(a)

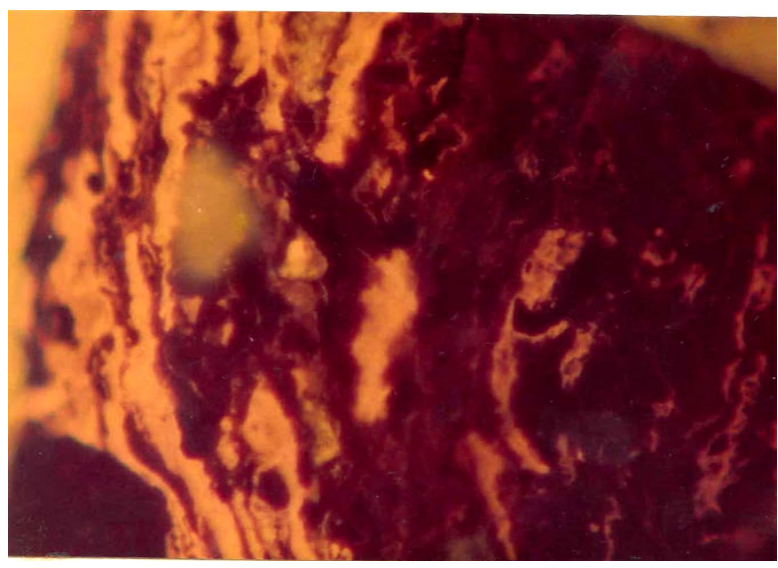

(b)

Figure 4. (a) Durite comprising fusinite and exinite under reflected light; (b) Durite comprising fusinite and exinite under fluorescent light.

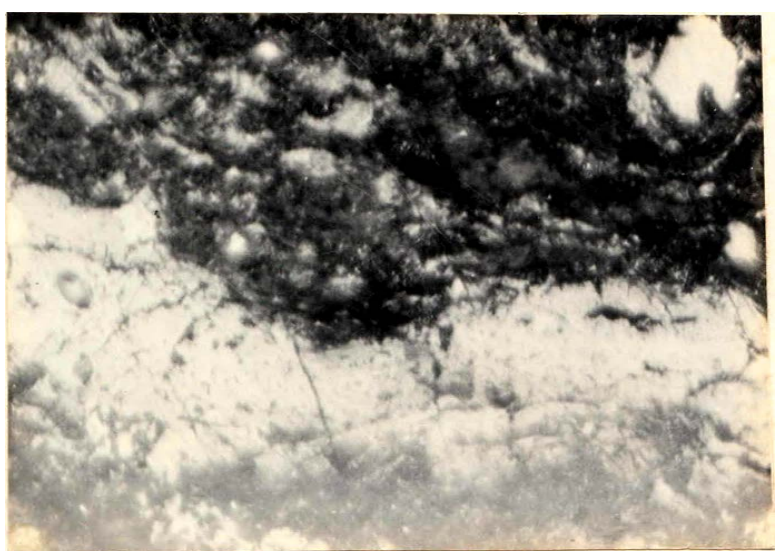

(a)

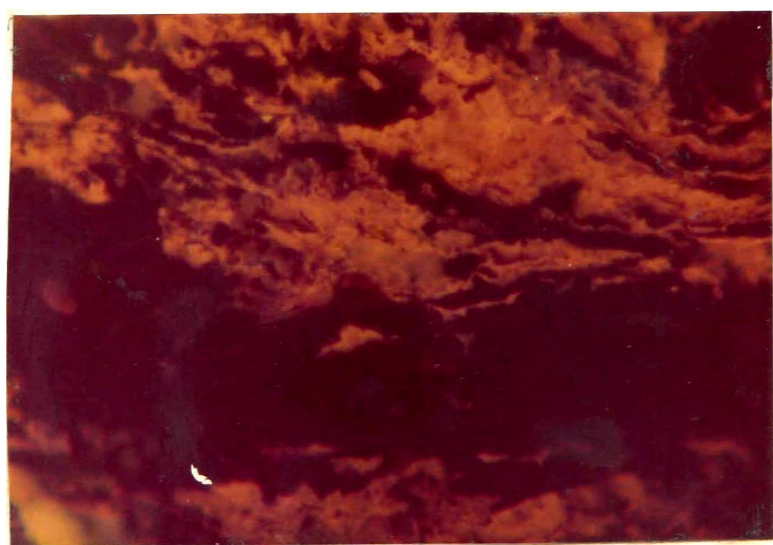

(b)

Figure 5. (a) Association of fusinite and sporinite under reflected light; (b) Association of fusinite and sporinite under fluorescent light. 
done. To have a clear picture of whole coalification process (reaction process) atomic ratios of H/C versus O/C were plotted on standard figures.

Proximate analysis of the coal samples were carried out by the Indian Standard Method (I.S.1977) [19] to determine the percentage of moisture, volatile matter and ash. Ultimate analysis of the samples was done following the Indian Standard Method (I.S.1974) [20]. In this analysis, the weight percentage of carbon, hydrogen and nitrogen were determined and the calorific value was also measured for all the samples.

\subsection{Proximate Analysis}

The proximate analysis of the Ib-valley coals (Table 4) shows that the percentage of moisture varies from 5.5\% to $16.1 \%$. Seam wise, the youngest Lajkura seam shows higher percentage of moisture than the Rampur and Ib seam coals. Similarly, the percentage of volatile matter varies from $17.2 \%$ to $32.9 \%$, the highest value being observed in the bottom most seam (Ib-seam). The Ash\% varies from $9.9 \%$ to $41.5 \%$. Comparatively, the lower seams contain less ash than the upper seams. Thus, the percentage of fixed carbon as determined from the above analysis varies from $26.8 \%$ to $50.2 \%$.

The fuel ratio is the ratio between fixed carbon percentage and volatile matter percentage. With the help of fuel ratio, the rank of coal can be determined. The fuel ratio of the samples analysed varied from 1.2 to 1.8 which is shown in Table 4. The seamwise variation of fuel ratio shows that the rank varies from the bottom to the top. The top Lajkura seam is comparatively lower in rank than the Ib and the Rampur seam.

Table 4. Proximate analysis of Ib-valley coals.

\begin{tabular}{|c|c|c|c|c|c|c|c|}
\hline Seam & Sample No. & Moisture (\%) & Ash (\%) & V.M. (\%)** & F.C. (\%) & Fuel Ratio & C.V \\
\hline \multirow{5}{*}{ Lajkura } & $\mathrm{L} / 5$ & 11.4 & 16.6 & 28.8 (40.9) & 43.2 & 1.5 & 5330 \\
\hline & $\mathrm{L} / 4$ & 13.2 & 30.1 & $25.1(46.7)$ & 31.6 & 1.3 & 3980 \\
\hline & $\mathrm{L} / 3$ & 16.1 & 29.7 & $24.4(47.6)$ & 29.8 & 1.2 & 3830 \\
\hline & $\mathrm{L} / 2$ & 9.0 & 41.5 & $22.7(50.0)$ & 26.8 & 1.2 & 3490 \\
\hline & $\mathrm{L} / 1$ & 15.5 & 19.9 & 27.4 (43.7) & 37.2 & 1.4 & 4860 \\
\hline \multirow{13}{*}{ Rampur } & $\mathrm{RS}_{5} / \mathrm{T}$ & 9.7 & 22.8 & 28.5 (43.69) & 39.0 & 1.4 & 4880 \\
\hline & $\mathrm{RS}_{5} / \mathrm{B}$ & 8.8 & 23.6 & $27.3(43.86)$ & 40.3 & 1.4 & 4950 \\
\hline & $\mathrm{RS}_{4} / \mathrm{T}$ & 8.1 & 30.8 & $22.4(38.6)$ & 38.7 & 1.7 & 4370 \\
\hline & $\mathrm{RS}_{4} / \mathrm{M}$ & 5.5 & 38.8 & 25.7 (49.5) & 30.0 & 1.02 & 4060 \\
\hline & $\mathrm{RS}_{4} / \mathrm{B}$ & 10.9 & 25.8 & $23.2(38.2)$ & 40.1 & 1.7 & 4620 \\
\hline & $\mathrm{RS}_{3} / \mathrm{T}$ & 6.7 & 26.5 & $27.5(42.86)$ & 39.3 & 1.4 & 4970 \\
\hline & $\mathrm{RS}_{3} / \mathrm{B}$ & 5.7 & 33.9 & $24.4(42.74)$ & 36.0 & 1.4 & 4270 \\
\hline & $\mathrm{RS}_{2} / \mathrm{T}$ & 8.1 & 14.0 & $28.2(36.86)$ & 49.7 & 1.8 & 6010 \\
\hline & $\mathrm{RS}_{2} / \mathrm{M}$ & 6.3 & 24.8 & $27.7(41.70)$ & 41.2 & 1.5 & 5270 \\
\hline & $\mathrm{RS}_{2} / \mathrm{B}$ & 7.1 & 13.9 & $28.8(37.10)$ & 50.2 & 1.7 & 6100 \\
\hline & $\mathrm{RS}_{1} / \mathrm{T}$ & 6.2 & 40.4 & $17.2(34.84)$ & 36.2 & 2.1 & 3800 \\
\hline & $\mathrm{RS}_{1} / \mathrm{M}$ & 10.6 & 12.5 & $29.6(39.12)$ & 47.3 & 1.6 & 5710 \\
\hline & $\mathrm{RS}_{1} / \mathrm{B}$ & 8.6 & 13.6 & 31.4 (41.07) & 46.4 & 1.5 & 5000 \\
\hline \multirow{4}{*}{$\mathrm{Ib}$} & $\mathrm{Ib} / \mathrm{T}$ & 9.9 & 15.4 & $32.3(44.14)$ & 42.4 & 1.3 & 5390 \\
\hline & $\mathrm{Ib} / \mathrm{M}_{2}$ & 7.4 & 33.8 & $24.9(44.92)$ & 33.9 & 1.4 & 4280 \\
\hline & $\mathrm{Ib} / \mathrm{M}_{1}$ & 8.9 & 9.9 & $32.9(41.01)$ & 48.3 & 1.5 & 6660 \\
\hline & $\mathrm{Ib} / \mathrm{B}$ & 12.1 & 12.6 & 31.6 (46.67) & 43.7 & 1.4 & 5560 \\
\hline
\end{tabular}




\subsection{Ultimate Analysis}

The results of the ultimate analysis of Ib valley coals are shown in Table 5. In these coals, the percentage of carbon ranges from $77.88 \%$ to $85.79 \%$ and the hydrogen percentage varies from $4.40 \%$ to $5.91 \%$. The carbon and hydrogen values indicate that the coals of the Ib valley are perhydrous to subhydrous by nature. There is not much variation in the nitrogen content. The values of all samples vary between a narrow range of $1.44 \%$ to $1.94 \%$. The oxygen content ranges from $7.26 \%$ to $15.3 \%$.

The elementary constitution of any term of the coalification series may be represented graphically by plotting $\mathrm{H} / \mathrm{C}$ vs $\mathrm{O} / \mathrm{C}$ ratio which gives an insight into the course of the process occupying during coalification. From the ultimate analysis data, the atomic ratios of $\mathrm{H} / \mathrm{C}$ and $\mathrm{O} / \mathrm{C}$ were calculated for different samples of the Ib-valley coals and the results are shown in Table 5. The values have been plotted on standard figures (Figure 6(a) and Figure 6(b)) after Van Krevelen (1961) [21].

The plotting on Figure 6(a) clearly indicate that these coals have low H/C ratio $(<1.0)$ and high $\mathrm{O} / \mathrm{C}$ atomic ratio. This is suggestive of type III kerogen formation in terrestrial environment. The organic matters were derived from continental higher plants and contain much identifiable vegetal debris. Microbial degradation in the basin of deposition is usually limited due to important sedimentation and rapid burial. In Figure 6(b), the evolution paths of the maceral groups of coals have been shown. The plotting of the coals of the Ib valley coalfield fall in vitrinite field, hence these are vitrinite rich coals formed by terrestrial origin.

\section{Conclusions}

1) The petrographic study reveals that the vitrinite percentage varies from $4.5 \%$ to $80.2 \%$, the exinite from $3.30 \%$ to $22.2 \%$ and the inertinite from $12.5 \%$ to $92.2 \%$ in different samples of the Ib valley coalfield. Normally, Indian coals are low in exinite content, but interestingly the exinite content of the Ib valley coals is higher (Table 3).

Table 5. Ultimate analysis of Ib-valley coals.

\begin{tabular}{|c|c|c|c|c|c|c|c|}
\hline Seam & Sample No. & C (\%) & $\mathrm{H}(\%)$ & $\mathrm{N}(\%)$ & $\mathrm{O}(\%)$ & $\mathrm{H} / \mathrm{C}$ & $\mathrm{O} / \mathrm{C}$ \\
\hline \multirow{5}{*}{ Lajkura } & $\mathrm{L} / 5$ & 81.23 & 5.14 & 1.46 & 12.17 & 0.759 & 0.112 \\
\hline & $\mathrm{L} / 4$ & 79.80 & 5.30 & 1.60 & 13.30 & 0.795 & 0.124 \\
\hline & $\mathrm{L} / 3$ & 81.86 & 5.91 & 1.85 & 10.38 & 0.863 & 0.094 \\
\hline & $\mathrm{L} / 2$ & 79.84 & 5.82 & 1.94 & 12.40 & 0.870 & 0.116 \\
\hline & $\mathrm{L} / 1$ & 80.60 & 5.59 & 1.69 & 12.12 & 0.833 & 0.112 \\
\hline \multirow{13}{*}{ Rampur } & $\mathrm{RS}_{5} / \mathrm{T}$ & 82.30 & 5.18 & 1.48 & 11.04 & 0.755 & 0.100 \\
\hline & $\mathrm{RS}_{5} / \mathrm{B}$ & 84.60 & 5.26 & 1.49 & 8.65 & 0.746 & 0.077 \\
\hline & $\mathrm{RS}_{4} / \mathrm{T}$ & 84.22 & 5.17 & 1.51 & 9.30 & 0.736 & 0.082 \\
\hline & $\mathrm{RS}_{4} / \mathrm{M}$ & 85.50 & 5.80 & 1.44 & 7.26 & 0.809 & 0.063 \\
\hline & $\mathrm{RS}_{4} / \mathrm{B}$ & 82.55 & 5.76 & 1.48 & 10.21 & 0.838 & 0.092 \\
\hline & $\mathrm{RS}_{3} / \mathrm{T}$ & 84.20 & 5.44 & 1.65 & 8.71 & 0.783 & 0.077 \\
\hline & $\mathrm{RS}_{3} / \mathrm{B}$ & 82.66 & 4.87 & 1.80 & 10.67 & 0.708 & 0.096 \\
\hline & $\mathrm{RS}_{2} / \mathrm{T}$ & 82.48 & 4.40 & 1.69 & 11.43 & 0.640 & 0.103 \\
\hline & $\mathrm{RS}_{2} / \mathrm{M}$ & 83.73 & 5.07 & 1.59 & 9.61 & 0.724 & 0.086 \\
\hline & $\mathrm{RS}_{2} / \mathrm{B}$ & 83.72 & 5.24 & 1.64 & 9.40 & 0.748 & 0.083 \\
\hline & $\mathrm{RS}_{1} / \mathrm{T}$ & 85.79 & 5.04 & 1.70 & 7.47 & 0.703 & 0.065 \\
\hline & $\mathrm{RS}_{1} / \mathrm{M}$ & 82.18 & 4.77 & 1.65 & 11.40 & 0.700 & 0.104 \\
\hline & $\mathrm{RS}_{1} / \mathrm{B}$ & 82.46 & 5.24 & 1.66 & 10.64 & 0.762 & 0.096 \\
\hline \multirow{4}{*}{$\mathrm{Ib}$} & $\mathrm{Ib} / \mathrm{T}$ & 77.88 & 5.09 & 1.73 & 15.3 & 0.783 & 0.147 \\
\hline & $\mathrm{Ib} / \mathrm{M}_{2}$ & 81.95 & 5.35 & 1.55 & 11.15 & 0.790 & 0.101 \\
\hline & $\mathrm{Ib} / \mathrm{M}_{1}$ & 80.05 & 4.97 & 1.62 & 13.36 & 0.750 & 0.125 \\
\hline & $\mathrm{Ib} / \mathrm{B}$ & 79.24 & 4.80 & 1.70 & 14.26 & 0.726 & 0.135 \\
\hline
\end{tabular}




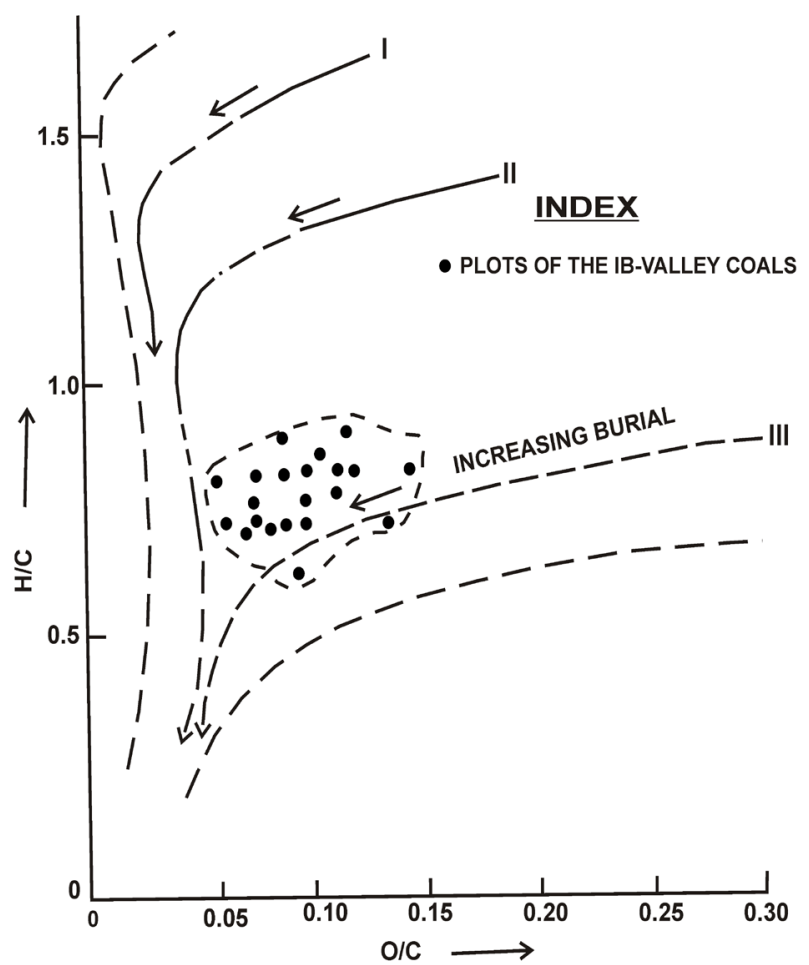

(a)
INDEX

- PLOTS OF THE IB-VALLEY COALS

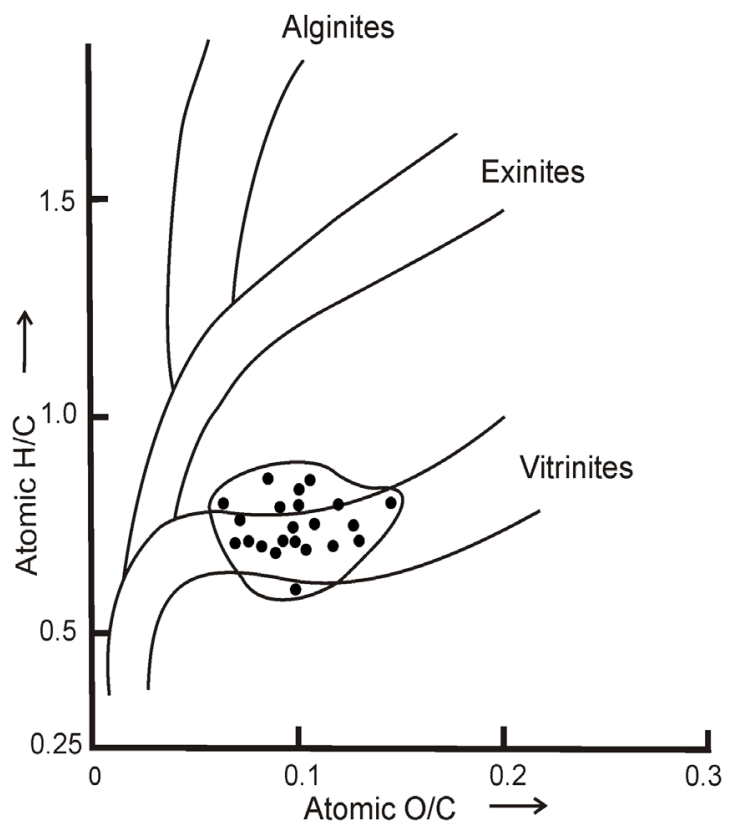

(b)

Figure 6. (a) Plotting of Ib-valley coals for depositional environment and kerogen formation (after Van Krevelin, 1961); (b) Plotting of the Ib-valley coal in the evolution paths of maceral groups (after Van Krevelin, 1961).

2) The very high proportion of inertinite obviously suggests a shallower water deposition of plant materials followed by prolonged period of exposure and repeated cycle of weathering.

3) Seamwise, the top Lajkura seam contains more of vitrinite and it gradually decreases towards the bottom seam whereas the exinite and exinite + vitrinie is low at the top seam and gradually increases towards the bottom. Inertinite doesn't show any variation from top to bottom.

4) Pyrite and other mineral matter vary from 1 to $16 \&$ in which pyrite alone contribute to $1 \%$ to $7 \%$. Also a number of colloidal forms of minerals which are suspected to be melnikovite (variety of pyrite group) are found in these coals.

5) On fluorescence studies, the Ib valley coals should have shown abundance of fluorescing macerals; but in the present study only a few fluorescing macerals have been observed. It may be due to paucity of exinite or liptinite materials. In exinites, sporinite and cutinite are the only dominant constituents intermingled with vitrinite (nonfluorescing). This also indicates that the vegetal tissues have not gone extensive lignifications which restricted the development of fluorescing property.

6) The proximate analysis revealed that the content of Ash, Moisture, Volatile matter and Fixed carbon was in the ranges of $9.9 \%$ to $41.5 \%, 5.5 \%$ to $16.1 \%, 17.2 \%$ to $32.9 \%$ and $26.8 \%$ to $50.2 \%$ respectively. Seam wise, the youngest Lajkura seam shows higher percentage of moisture and volatile matter than the older seams. Similarly, the lower seams were observed to contain less ash than the upper seams. Thus, the variation of Moisture, Ash, Volatile Matter and Fixed carbon in the coal seams shows a definite trend with stratigraphy.

7) The percentage of variation in $\mathrm{C}$ is found from 77.88 to $85.79, \mathrm{H}$ from 4,4 to 5.91 and $\mathrm{O}$ from 7.26 to 15.3 . $\mathrm{H} / \mathrm{C}$ and $\mathrm{O} / \mathrm{C}$ ratio including C.V. in this coalfield shows distinct variations from the bottom to top sea $\mathrm{m}$, thus indicating a relation with stratigraphy of the seams.

8) The chemical analysis indicates that the younger Lajkura seam is lower in rank compared with the Ib and the Rampur seam. Proximate analysis shows that the Ib vally coals are sub-bituminous in rank and consist of high volatile matter and increased levels of inorganics (Table 4).

9) The coals of the Ib valley coalfield have low $\mathrm{H} / \mathrm{C}$ and high $\mathrm{O} / \mathrm{C}$ ratio. This is suggestive of type-III kerogen formation in terrestrial environment. The organic matters are derived from continental higher plants and contain 
much identifiable vegetal debris. Microbial degradation is less due to sedimentation and rapid burial.

10) The environment of deposition and kerogen formation is shown in Figure 6(a) and the sample cluster indicates type II and type III kerogen field.

11) The H/C vs O/C diagram also indicates that the evolution paths of the macerals fall in the vitrinite field because of terrestrial depositional environment (Figure 6(b)).

\section{References}

[1] Pareek, H.S. (1958) A Note on the Petrology of Ib River Coals. Quart. Jour. Geol. Min.Met. Soc. Ind, 9.

[2] Navale, G.K.B. (1967) Microconstituent Analysis of Coal Seams in Hingir-Rampur Coalfield, U.G.C. Sponsored Symposium: “Coal; A Pterographic Approach”.

[3] Navale, G.K.B. and Tiwari, R.S. (1968) Palynological Correlation of Coal Seams, Their Nature and Formation in Rampur Coalfield, Lower Gondwana (India). The Review of Palaeobotany and Palynology, 6, 155-169. http://dx.doi.org/10.1016/0034-6667(68)90043-2

[4] Behera, P. and Chandra, D. (1995) Spontaneous Combustion of the Ib Valley Coals of Orissa (India)—A DTA Study. Minetech, 16, 52-57.

[5] Goswami, S., Das, M. and Guru, B.C. (2006) Permian Biodiversity of Mahanadi Master Basin, Orissa, India and Their Environmental Countenance. Acta Palaeobotanica, 46, 101-118.

[6] Singh, R.K., Singh, K.N., Dhanoria, S.K., Bhatt, A. and Dixit, A. (2010) Petrochemistry and Depositional Environment of Permian Coals of Basundhara Block, Ib-Valley Coalfield, Orissa, India. International Journal of Economic and Environment Geology, 1, 36-41.

[7] Mohanty, D., Kumar, S., Boral, P. and Choudhury, N. (2011) Petrographic Signatures of Marine Inundation from the Barakar Coal Measures of Mahanadi-Ib Valley, Orissa, India. Current Science, 101, 1149-1155.

[8] Senapaty, A. and Behera, P. (2012) Study of Selected Trace Elements in Coal and Groundwater of the Ib-valley Coalfield of Odisha, India and Their Possible Impact on Human Health. The International Journal of Earth Sciences and Engineering, 5, 1241-1248.

[9] Singh, P.K., Singh, G.P., Singh, M.P. and Naik, A.S. (2013) The Petrology of Coals from the Rampur Seam-IV and the Lajkura Seam, Ib River Coalfield, Mahanadi Valley, Orissa, India. Energy Sources, Part A, 35, 1681-1690. http://dx.doi.org/10.1080/15567031003663158

[10] Manjrekar, V.D., Choudhury, V. and Gautam K.V.V.S. (2006) Coal. In: Mahalik, N.K., Ed., Geology and Mineral Resources of Orissa, Society of Geoscientists and Allied Technologist, Bhubaneswar, 205-226.

[11] ICCP (1971) International Hand book of Coal Petrology. Supplement to 2nd Edition, International Committee of Coal Petrology, cent., Natl., Sci., Paris.

[12] ICCP (1998) The New Vitrinite Classification (ICCP System, 1994). Fuel, 77, 349-358. http://dx.doi.org/10.1016/S0016-2361(98)80024-0

[13] ICCP (2001) The New Vitrinite Classification (ICCP System, 1994). Fuel, 80, 459-471. http://dx.doi.org/10.1016/S0016-2361(00)00102-2

[14] ICCP (1963) International Hand book of Coal Petrology. 2nd Edition, International Committee of Coal Petrology, cent., Natl., Sci., Paris.

[15] ICCP (1975) International Hand book of Coal Petrology. 2nd Supplement to 2nd Edition, International Committee of Coal Petrology, cent., Natl., Sci., Paris.

[16] Diessel, C.F.K. (1965) Correlation of Macro- and Micro-Petrography of Some New South Wales Coals. Proceedings of the 8th Commonwealth Mining and Metallurgical Congress, Vol. 6, Melbourne, Date, 669-677.

[17] Chandra, D. and Taylor, G.H. (1975) Thermally Altered Coals. Stach’s Text Book of Coal Petrology. Gebrüder Borntraeger, Berlin, 164-175.

[18] Niyogi, C. (1989) Studies of Spontaneous Combustion of Coal of Talcher Coalfield. Unpublished Ph.D. Thesis, Indian School of Mines, Dhanbad.

[19] Indian Standard (1977) Methods of Test for Coal and Coke, Part-I, Proximate Analysis. 1st Revision, 2nd Reprint 1977.

[20] Indian Standard (1974) Methods of Test for Coal and Coke, Part-IV, Ultimate Analysis. September 1974.

[21] Van Krevelen, D.W. (1961) Coal. Elsevier Publishing Company, New York, 113-120. 